\title{
PENGARUH PEMBERIAN YOGHURT KORO PEDANG (CANAVALIA ENSIFORMIS) TERHADAP KADAR SERUM TRIGLISERIDA TIKUS SPRAGUE DAWLEY HIPERTRIGLISERIDEMIA
}

\author{
Widya Ayu Wulandari, Adriyan Pramono*) \\ Program Studi Ilmu Gizi Fakultas Kedokteran Universitas Diponegoro \\ J1.Dr.Sutomo No.18, Semarang, Telp (024) 8453708, Email : gizifk@ undip.ac.id
}

\begin{abstract}
ABSTRCT
Backgroud : Hypertriglyceridemia is a condition which characterized by increased triglycerides Level. Jack bean contains isoflavones, tannins, saponins, fiber and protein that potentially lower triglyceride levels. Yoghurt contains lactic acid bacteria which can decrease triglycerides levels. The making process and fermentation of jack bean can increase its isoflavon's activity by forming aglicone, which has higher activity.

Methods : This study was a true experiment with pre-post test randomized control group design. The subjects were male Sprague-dawley rats aged 3 months, 21 tails induced dyslipidemia. Control group was not consume the jack bean yoghurt, treatment group $1(P 1)$ consume the jack bean yoghurt at doseges $2,1 \mathrm{ml}$, and treatment group 2(P2) consume the jack bean yoghurt at doseges $4,5 \mathrm{ml}$ for 21 days. Triglyceride serum was measured by CHOD-PAP

Result: Triglyceride level in $K$ group increased from 58,73mg/dl to $61,71 \mathrm{mg} / \mathrm{dl}$, P1 group increased from $53,69 \mathrm{mg} / \mathrm{dl}$ to $58,10 \mathrm{mg} / \mathrm{dl}$ dan P2 group increased from 51,44 mg/dl to 56,50mg/dl. Based on Paired t_test based test showed a non-significant increase in triglycerides and ANOVA test showed no significant difference in the change in triglyceride levels between groups. Conclusion: Jack bean yoghurt dosages of 2,1 ml and jack bean yoghurt at dosages 4,5ml for 21 days not reduced the triglycerides levels on rats.
\end{abstract}

Key words : jack bean; yoghurt; triglycerides; hypertriglyceridemia

\section{ABSTRAK}

Latar Belakang : Hipertrigliseridemia ditandai dengan meningkatnya kadar trigliserida dalam darah. Koro pedang mengandung isoflavon, tanin, saponin, serat dan protein yang berpotensi menurunkan kadar trigliserida. Yoghurt mengandung bakteri asam laktat yang dapat menurunkan kadar trigliserida. Proses pengolahan dan fermentasi dapat meningkatkan aktivitas antioksidan dengan menghidrolisis isoflavon menjadi aglikon yang lebih tinggi aktivitasnya.

Metode : Desain penelitian ini adalah true experiment dengan pre-post test with randomized control group design. Subjek penelitian adalah tikus jantan sprague dawley berusia 3 bulan sebanyak 21 ekor yang diinduksi hipertrigliseridemia. Subjek dibagi menjadi 3 kelompok, kelompok kontrol (K) tidak diberi yoghurt koro pedang, kelompok perlakuan $1(P 1)$ diberi yogurt koro pedang 2,1ml dan kelompok perlakuan 2 (P2) diberi yoghurt koro pedang 4,5ml selama 21 hari. Pengukuran kadar trigliserida serum menggunakan metode GPOP-PAP.

Hasil : Kadar trigliserida pada kelompok $K$ naik dari 58,73 mg/dl menjadi $61,71 \mathrm{mg} / \mathrm{dl}$, kelompok P1 naik dari 53,69mg/dl menjadi 58,10 mg/dl dan kelompok P2 naik dari 51,44 mg/dl menjadi 56,50mg/dl. Berdasarkan uji Paired t_test menunjukan peningkatan trigliserida yang tidak bermakna dan uji Anova menunjukan tidak terdapat perbedaan yang bermakna pada perubahan kadar trigliserida antar kelompok.

Simpulan : Pemberian yoghurt koro pedang dengan dosis 2,1ml dan 4,5ml selama 21 hari tidak dapat menurunkan kadar trigliserida pada tikus.

Kata Kunci : Koro pedang; yoghurt; trigliserida; hipertrigliseridemia

\section{PENDAHULUAN}

Hipertrigliseridemia merupakan salah satu faktor risiko terjadinya penyakit kardiovaskuler yang ditandai dengan tingginya trigliserida. Kadar trigliserida yang tinggi dapat mengakibatkan terjadinya atherosklerosis melalui peningkatan kilomokron dan Very Low Density Lipoprotein (VLDL). Kilomikron dan VLDL bersifat aterogenik yaitu mempunyai aktivitas platelet (pembentukan plak) dan mempercepat pembekuan darah. Hal tersebut dapat menghambat peredaran darah ke jantung yang dapat berakibat terjadinya kematian. ${ }^{1-3} \quad$ Kematian akibat penyakit kardiovaskuler di Indonesia menurut World Health Organization (WHO) sebesar 30\% pada tahun 2008. ${ }^{4}$

Pengaturan pola makan atau diet merupakan salah satu upaya dalam menurunkan trigliserida. Penurunan kadar trigliserida dilakukan dengan membatasi konsumsi makanan yang mengandung kolesterol, lemak jenuh dan karbohidrat sederhana. $^{5}$ Selain itu, untuk 
menurunkan trigliserida juga dapat dilakukan melalui konsumsi bahan makanan seperti koro pedang. ${ }^{6,7}$

Koro pedang mempunyai potensi menurunkan trigliserida karena kandungan isoflavon, tanin, saponin dan serat. Mekanisme penurunan trigliserida melalui penghambat absorbsi lemak dan karbohidrat di usus halus, peningkatan lipolisis, peningkatan eksresi asam empedu dan trigliserida melalui feses. ${ }^{6-9}$

Penelitian yang dilakukan pada tikus diabetik dengan hiperkolesterolemia dan hiperketonaemia menunjukan bahwa pemberian ekstrak koro pedang sebanyak $400 \mathrm{mg} / \mathrm{kg}$ berat badan tikus selama 7 hari dapat menurunkan kolesterol total $(39,6 \%)$ dan trigliserida $(58,5 \%)$ serum secara signifikan. ${ }^{9}$

Yoghurt merupakan hasil fermentasi susu dengan bakteri asam laktat (BAL) seperti Streptococcus thermophillus, Lactobacillus bulgaricus dan Lactobaccilus casei. ${ }^{10}$ Penelitian terdahulu menyebutkan bahwa pemberian yoghurt kedelai hitam dengan bakteri Streptococcus thermophillus dan Lactobacillus bulgaricus sebanyak $115 \mathrm{ml} /$ hari dapat menurunkan LDL, kolesterol total dan trigliserida. ${ }^{11,12}$ Penelitian lain menyebutkan bahwa pemberian yoghurt dengan bakteri Streptococcus thermophillus dan Lactobacillus bulgaricus sebanyak $250 \mathrm{ml} / \mathrm{hari}$ dapat menurunkan trigliserida secara signifikan. ${ }^{13}$ Berdasarkan penelitian sebelumnya, bakteri asam laktat berpotensi menurunkan kadar kolesterol darah melalui mekanisme asimilasi kolesterol, dekonjugasi asam empedu, mengubah kolesterol mejadi koprostanol dan memproduksi asam lemak pendek. ${ }^{10-15}$ Proses pengolahan dan fermentasi dapat meningkatkan aktivitas antioksidan, dimana terjadi hidrolisa senyawa isoflavon menjadi senyawa bebas atau aglikon yang lebih tinggi aktivitasnya. ${ }^{8,10}$

Susu koro pedang yang difermentasi dengan BAL menghasilkan yoghurt koro pedang. Yoghurt koro pedang merupakan upaya dalam meningkatkan daya terima dan manfaat dari koro pedang sebagai makanan fungsional. Pemilihan tikus jantan Sprague dawley sebagai hewan coba karena memiliki persamaan karakteristik biologi dengan manusia dan lebih sensitif terhadap perlakuan. ${ }^{16}$

\section{METODE PENELITIAN Subjek}

Subjek yang digunakan dalam penelitian ini adalah tikus putih bergalur Sprague dawley, berkelamin jantan, umur 3 bulan, berat badan 190260 gr yang diperoleh dari Laboratorium Penelitian dan Pengujian Terpadu (LPPT) Universitas Gajah Mada.

\section{Bahan}

Bahan yang digunakan dalam penelitian ini meliputi pakan tinggi lemak, yoghurt koro pedang, aquadest dan pakan standar AD II. Pakan tinggi lemak yang digunakan berupa otak sapi. Otak sapi sebelumnya dikukus dan diblender (perbandingan otak sapi dan aquadest 1:1).

Proses pembuatan yoghurt koro pedang dimulai dengan membuat susu koro pedang. Susu koro pedang dibuat dengan metode Cornel yang telah dimodifikasi. ${ }^{17}$ Biji koro pedang direndam selama 24 jam (perbandingan koro pedang dan air 1:10), dibersihkan kulitnya dan dicuci sebanyak dua kali. Koro pedang direbus (perbandingan koro pedang dan air 1:5) selama 20 menit kemudian koro pedang diblender (perbandingan koro pedang dengan air panas 1:6) dan disaring. Susu yang dihasilkan kemudian dimasak hingga mencapai suhu pasteurisasi $\left(80-85^{\circ} \mathrm{C}\right)$ selama 20 menit.

Pembuatan yoghurt koro pedang sesuai metode Kanda yang telah dimodifikasi. ${ }^{18}$ Setelah terjadi penurunan suhu menjadi $70^{\circ} \mathrm{C}$, ditambahkan gula pasir sebanyak 3\% dan susu skim sebanyak $5 \%$ dari volume susu koro pedang serta diaduk sampai homogen. Kemudian dilanjutkan dengan penurunan suhu koro pedang pedang hingga 37$40^{\circ} \mathrm{C}$ untuk mengkondisikan suhu pertumbuhan starter Lactobacillus bulgaricus dan Streptococcus thermopillus. Bakteri Lactobacillus bulgaricus dan Streptococcus thermophillus dengan perbandingan 1:1 ditambahkan pada susu koro pedang sebanyak $3 \%$ dari volume susu koro pedang. Susu koro pedang kemudian diinkubasi pada suhu $35-37^{\circ} \mathrm{C}$ pada inkubator selama 4 jam hingga mencapai $\mathrm{pH}$ 4,4 - 4,6.

Komposisi pakan standar AD II berupa jagung kuning, soy bean meal, meat bone meal, corn glutein meal, palm olein, asam amino esensial, mineral esensial, premix dan vitamin. Dalam $100 \mathrm{~g}$ pakan standar AD II berupa karbohidrat $51 \%$, protein kasar $15 \%$, lemak kasar $3-7 \%$, serat kasar 6\%, abu 7\%, kalsium 0,9-11\%, fosfor $0,6-0,9 \%$, air $12 \%$ dan antibiotika.

\section{Metode Penelitian}

Penelitian ini berjenis true experiment dengan pre-post test with randomized control group design. Variabel bebas dan terikat dalam penelitian ini adalah yoghurt koro pedang dan kadar trigliserida serum tikus Sprague dawley dislipidemia. 


\section{Tahap Pelaksanaan}

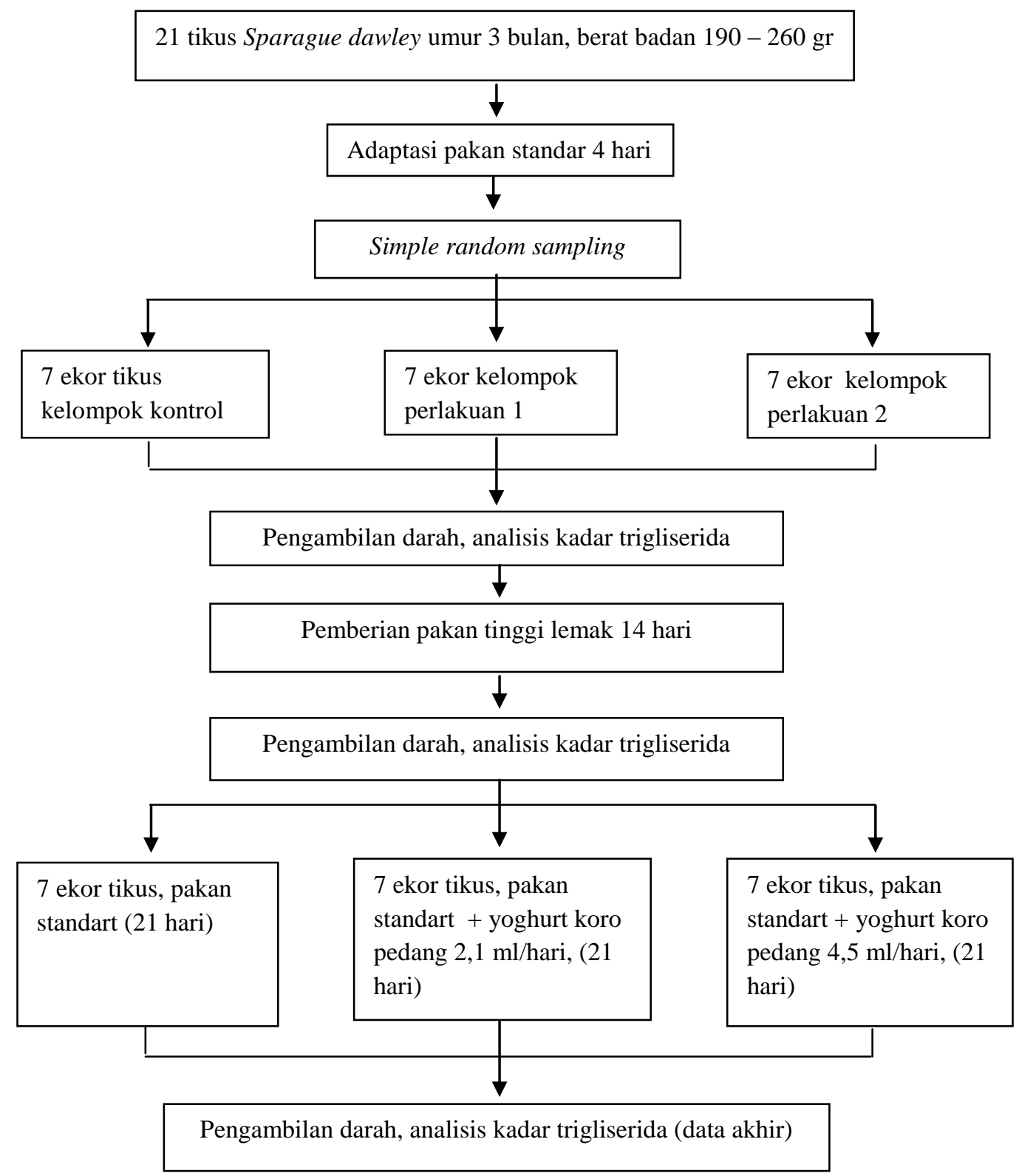

Gambar 1. Bagan Alur Penelitian

Penentuan jumlah subjek penelitian menggunakan ketentuan WHO, dimana jumlah minimal subjek setiap kelompok adalah 5 subjek. ${ }^{19}$ Pada penelitian ini terdapat dua kelompok perlakuan dan satu kelompok kontrol. Untuk mengantisipasi adanya tikus yang dropout maka ditambah 2 subjek tiap kelompok. Sehingga berdasarkan ketentuan tersebut didapatkan 21 subjek dan setiap kelompok berjumlah 7 subjek.

Subjek dipelihara dalam ruangan berventilasi cukup dan dikandangkan secara individual. Suhu ruangan berkisar antara $25-28^{\circ} \mathrm{C}$, siklus pencahayaan 12 jam (siklus terang 06.00 -
18.00) dan kandang dibersihkan setiap hari. Seluruh subjek diadaptasi selama 4 hari, diberi pakan standar sebanyak 20 gr/hari dan minum air secara ad libitum. Kemudian subjek penelitian dikelompokkan dengan cara simple random sampling dan dibagi menjadi 3 kelompok yaitu :

$\mathrm{K} \quad=$ kelompok kontrol (pakan tinggi lemak)

$\mathrm{P} 1=$ kelompok perlakuan 1 (pakan tinggi lemak+ yoghurt 2,1 ml)

P2 = kelompok perlakuan 2 (pakan tinggi lemak+ yoghurt 4,5 ml)

Pemberian pakan tinggi lemak berupa otak sapi sebanyak $2 \mathrm{ml} /$ hari yang diberikan pada ketiga 
kelompok selama 14 hari. Setelah itu kelompok kontrol diberi pakan standar selama 21 hari. Sedangkan kelompok perlakuan diberi pakan standar dan diberi yoghurt koro pedang dengan cara sonde selama 21 hari.

Penelitian terdahulu menyebutkan bahwa pemberian yoghurt kedelai hitam dengan bakteri Streptococcus thermophillus dan Lactobacillus bulgaricus sebanyak $115 \mathrm{ml} / \mathrm{hari}$ dapat menurunkan LDL, kolesterol total dan trigliserida. ${ }^{11,12}$ Penelitian lain menyebutkan bahwa pemberian yoghurt dengan bakteri Streptococcus thermophillus dan Lactobacillus bulgaricus sebanyak $250 \mathrm{ml} / \mathrm{hari}$ dapat menurunkan trigliserida secara signifikan. ${ }^{13}$ Kemudian dosis ini dikonversi dengan dosis untuk tikus dengan berat badan 200 gr, diperoleh dosis pemberian 2,1 ml dan $4,5 \mathrm{ml}^{20}$

Pengambilan darah dilakukan sebanyak 3 kali yaitu setelah subjek diadaptasi, setelah pemberian pakan tinggi lemakdan setelah pemberian yoghurt koro pedang. Darah subjek diambil melalui plexus retroorbitalis tikus Sprague dawley sebanyak $2 \mathrm{ml}$ dimasukkan ke dalam tabung bersih dan disentifuge untuk mendapatkan serumnya. Penentuan kadar trigliserida dilakukan menurut metode Gluycerol
Phosphate Oxydae - Phenyl Amino Phyrazolon (GPO-PAP). ${ }^{21}$

Data hasil pengukuran trigliserida yang diperoleh kemudian diolah dengan program komputer. Data tersebut diuji normalitasnya dengan uji Shapiro-wilk. Perbedaan kadar trigliserida serum sebelum dan sesudah pemberian pakan tinggi lemak diuji dengan Paired t-test jika data berdistribusi normal. Selanjutnya dilakukan uji beda tiap kelompok antara sebelum dan sesudah pemberian yoghurt koro pedang pada berbagai dosis pemberian. Perbedaan pengaruh dari ketiga kelompok perlakuan dianalisis menggunakan uji statistik Anova jika data normal. ${ }^{22}$

\section{HASIL PENELITIAN}

Jumlah subjek pada penelitian ini sebanyak 21 subjek kemudian dibagi menjadi 3 kelompok yaitu kelompok kontrol (K), kelompok perlakuan 1(P1) dan kelompok perlakuan 2 (P2).

Dua puluh satu tikus Sprague dawley jantan dipelihara dalam kandang individu. Pemeliharaan dan pembersihan kandang dilakukan setiap hari oleh peneliti. Penimbangan berat badan dan sisa pakan dilakukan setiap hari selama penelitian.

Tabel 1. Hasil Analisis Rerata Berat Badan Subjek Selama Sebelum dan Setelah Pemberian Yoghurt Koro Pedang

\begin{tabular}{|c|c|c|c|c|}
\hline \multirow[t]{2}{*}{ Kelompok } & \multicolumn{2}{|c|}{ Rerata $\pm \mathrm{SD}(\mathrm{mg} / \mathrm{dl})$} & \multirow[t]{2}{*}{$\Delta$ Rerata } & \multirow[t]{2}{*}{$P$} \\
\hline & Sebelum & Sesudah & & \\
\hline K & $247,65 \pm 27,42$ & $269,73 \pm 27,61$ & $22,08 \pm 9,13^{\mathrm{a}}$ & $0,001^{\mathrm{b}}$ \\
\hline $\mathrm{P} 1$ & $248,53 \pm 23,64$ & $268,14 \pm 22,27$ & $19,61 \pm 3,24^{\mathrm{a}}$ & $0,000^{\mathrm{b}}$ \\
\hline P2 & $226,61 \pm 22,72$ & $244,94 \pm 26,87$ & $18,33 \pm 13,77^{a}$ & $0,013^{b}$ \\
\hline
\end{tabular}

Berdasarkan data yang ditunjukan tabel 1, pedang. Hasil analisis perubahan berat badan diketahui terdapat peningkatan berat badan pada subjek menunjukkan bahwa tidak terdapat kelompok K, P1 dan P2 yang bermakna antara perbedaan rerata barat badan antar kelompok sebelum dan sesudah pemberian yoghurt koro perlakuan $(p=0,767)$.

Tabel 2. Rerata Total Kalori Asupan Subjek Selama Sebelum dan Setelah Pemberian Yoghurt Koro Pedang

\begin{tabular}{|c|c|c|c|c|}
\hline \multirow[t]{2}{*}{ Kelompok } & \multicolumn{2}{|c|}{ Rerata $\pm \mathrm{SD}(\mathrm{mg} / \mathrm{dl})$} & \multirow[t]{2}{*}{$\Delta$ Rerata } & \multirow[t]{2}{*}{$P$} \\
\hline & Sebelum & Sesudah & & \\
\hline $\mathrm{K}$ & $47,27 \pm 5,07$ & $51,52 \pm 5,03$ & $4,25 \pm 4,21^{\mathrm{a}}$ & $0,037^{\mathrm{b}}$ \\
\hline $\mathrm{P} 1$ & $42,33 \pm 3,46$ & $46,93 \pm 3,07$ & $4,60 \pm 3,12^{\mathrm{a}}$ & $0,008^{b}$ \\
\hline $\mathrm{P} 2$ & $42,33 \pm 4,43$ & $47,43 \pm 6,48$ & $5,10 \pm 4,15^{\mathrm{a}}$ & $0,017^{\mathrm{b}}$ \\
\hline
\end{tabular}

${ }^{\mathrm{a}}$ Uji Anova

${ }^{\mathrm{b}}$ Uji Paired t-test 
Terdapat peningkatan total kalori asupan yang bermakan pada kelompok $\mathrm{K}, \mathrm{P} 1$ dan P2 selama sebelum dan setelah pemberian yoghurt koro pedang. Hasil analisis perubahan total kalori asupan subjek menunjukkan bahwa tidak terdapat perbedaan total kalori asupan antar kelompok perlakuan $(p=0,917)$. Peningkatan berat badan subjek seiring dengan meningkatnya total kalori asupan subjek.

Tabel 3. Kadar Trigliserida Sebelum dan Setelah Pemberian Pakan Tinggi Lemak

\begin{tabular}{|c|c|c|c|c|}
\hline \multirow[t]{2}{*}{ Kelompok } & \multicolumn{2}{|c|}{ Rerata $\pm \mathrm{SD}(\mathrm{mg} / \mathrm{dl})$} & \multirow[t]{2}{*}{$\Delta$ Rerata } & \multirow[t]{2}{*}{$P$} \\
\hline & Sebelum & Sesudah & & \\
\hline $\mathrm{K}$ & $50,99 \pm 15,18$ & $58,73 \pm 11,67$ & $7,74 \pm 10,94^{\mathrm{a}}$ & $0,110^{\mathrm{b}}$ \\
\hline $\mathrm{P} 1$ & $47,13 \pm 12,62$ & $53,69 \pm 13,11$ & $6,52 \pm 8,28^{a}$ & $0,082^{b}$ \\
\hline $\mathrm{P} 2$ & $44,94 \pm 14,09$ & $51,44 \pm 16,09$ & $6,50 \pm 9,43^{\mathrm{a}}$ & $0,118^{\mathrm{b}}$ \\
\hline
\end{tabular}

Terjadi peningkatan kadar trigliserida yang tidak bermakna setelah pemberian pakan tinggi lemakpada kelompok K, P1 dan P2. Uji beda antar kelompok menunjukan tidak ada perbedaan yang bermakna kadar trigliserida antar kelompok setelah pemberian pakan tinggi lemak $(p=0,963)$.

Tabel 4. Kadar Trigliserida Sebelum dan Setelah Pemberian Yoghurt Koro Pedang

\begin{tabular}{|c|c|c|c|c|}
\hline \multirow[t]{2}{*}{ Kelompok } & \multicolumn{2}{|c|}{ Rerata $\pm \mathrm{SD}(\mathrm{mg} / \mathrm{dl})$} & \multirow[t]{2}{*}{$\Delta$ Rerata } & \multirow[t]{2}{*}{$P$} \\
\hline & Sebelum & Sesudah & & \\
\hline K & $58,73 \pm 11,67$ & $62,26 \pm 11,66$ & $3,53 \pm 4,16^{\mathrm{a}}$ & $0,066^{\mathrm{b}}$ \\
\hline $\mathrm{P} 1$ & $53,69 \pm 13,11$ & $57,44 \pm 10,89$ & $3,78 \pm 4,15^{\mathrm{a}}$ & $0,053^{b}$ \\
\hline $\mathrm{P} 2$ & $51,44 \pm 16,09$ & $56,50 \pm 16,03$ & $5,05 \pm 5,88^{\mathrm{a}}$ & $0,063^{\mathrm{b}}$ \\
\hline
\end{tabular}

Tabel 4 menunjukan terjadinya peningkatan kadar trigliserida yang tidak bermakna setelah pemberian yoghurt koro pedang pada kelompok K, P1 dan P2. Uji beda antar kelompok

\section{PEMBAHASAN}

Pakan tinggi lemak yang digunakan dalam penelitian ini adalah otak sapi. Dalam $100 \mathrm{~g}$ otak sapi mengandung sekitar 2,9 $\mathrm{g}$ asam lemak jenuh. Setelah pemberian otak sapi sebanyak $2 \mathrm{ml}$ selama 14 hari terdapat peningkatan kadar trigliserida yang tidak bermakna pada kelompok K, P1 dan P2. Asam lemak jenuh yang dikonsumsi dari makanan akan melalui proses pencernaan dan diabsorpsi. Pada proses absorbsi di mukosa usus halus, asam lemak jenuh diaktifkan menjadi asil koA oleh enzim tiokinase, kemudian asil koA mengalami proses esterifikasi dimana terjadi penambahan gliserol 3 fosfat yang membentuk trigliserida. ${ }^{1,23}$ Trigliserida diangkut dalam bentuk kilomikron menuju ke peredaran darah limfa yang kemudian masuk ke peredaran darah. Pada saat di jaringan ekstrahepatik enzim lipoprotein lipase menunjukan tidak ada perbedaan kadar trigliserida yang bermakna antar kelompok setelah pemberian yoghurt koro pedang $(p=0,784)$.

\section{Kadar Trigliserida Setelah Pemberian Pakan Tinggi Lemak}

menghidrolisis trigliserida dan kilomikron menjadi asam lemak bebas dan kilomikron remnant. ${ }^{23} \mathrm{Asam}$ lemak bebas diambil oleh jaringan tubuh untuk diubah menjadi trigliserida sebagai bentuk cadangan energi dan kilomikron remnant kembali ke hati untuk berinteraksi dengan partikel remnant lainya membentuk spesifik reseptor untuk apoliporotein $\mathrm{E}$ atau B pada sel. ${ }^{23}$

Terdapat 2 subjek tiap kelompok yang mengalami penurunan kadar trigliserida setelah diberi otak sapi. Penurunan kadar trigliserida diduga karena kandungan MUFA pada otak sapi, dalam 100gr otak sapi mengandung 1,8 gr MUFA. Terdapat dua kemungkinan mekanisme dari MUFA yang saling melengkapi yaitu perubahan komposisi VLDL dan perubahan aktivitas enzim serta protein yang terlibat dalam proses 
katabolisme VLDL. ${ }^{24}$ Komposisi asam lemak dari makanan menentukan konversi VLDL pada lipoprotein lain dan metabolisme trigliserida. ${ }^{24}$

\section{Kadar Trigliserida Setelah Pemberian Yoghurt Koro Pedang}

Hasil penelitian menunjukan terdapat perbedaan kadar trigliserida antara sebelum dan sesudah pemberian yoghurt koro pedang selama 21 hari pada semua kelompok perlakuan. Pada kelompok K, P1 dan P2 terjadi kenaikan kadar trigliserida $(p<0,05)$. Pada kelompok $\mathrm{K}$ hanya diberikan pakan standar dan mengalami kenaikan trigliserida sebanyak 6,01\%. Pada kelompok P1 yang diberikan pakan standar dan yoghurt koro pedang sebanyak $2,1 \mathrm{ml}$ mengalami kenaikan trigliserida sebanyak 7,04\%. Pada kelompok P2 mengalami kenaikan trigliserida sebanyak $9,83 \%$ dengan pemberian pakan standar dan yoghurt koro pedang sebanyak $4,5 \mathrm{ml}$. Hasil analisis perubahan kadar trigliserida menunjukan tidak terdapat perbedaan kadar trigliserida antar kelompok $\mathrm{K}, \mathrm{P} 1$ dan $\mathrm{P} 2(p=0,784)$.

Penelitian terdahulu menyebutkan pemberian ekstrak koro pedang sebanyak 400 $\mathrm{mg} / \mathrm{kg}$ berat badan tikus selama 7 hari dapat menurunkan trigliserida, namun pada penelitian ini yoghurt koro pedang tidak dapat menurunkan kadar trigliserida. Hal yang membedakan penelitian ini dengan penelitian sebelumnya adalah bentuk sediaan koro pedang yang diberikan untuk menurunkan trigliserida. Bentuk sediaan ekstrak dimungkinkan lebih tinggi kandungan zat fitokimia dibandingkan dengan yoghurt koro pedang.

Pada proses pengolahan koro pedang menjadi yoghurt koro pedang dimungkinkan terjadi penurunan kandungan zat - zat fitokimia yang terdapat pada koro pedang. Pada proses pemasakan dengan suhu $100^{\circ} \mathrm{C}$ tanin dapat berkurang sebanyak $64 \% .{ }^{11} \mathrm{Hal}$ ini diduga sebagai penyebab efek dari pemberian yoghurt koro pedang tidak sesuai dengan penelitian terdahulu yang menyebutkan pemberian ekstrak koro pedang dapat menurunkan kadar trigliserida.

Pada koro pedang terdapat kandungan alkaloid $(0,614 \pm 0,2 \mathrm{~g} / 100 \mathrm{~g})$ yang mempunyai sifat hipokolesterol $^{25,26}$ Selain mempunyai sifat hipokolesterol, alkaloid dapat menyebabkan terjadinya hepatotoksik dimana terjadi kerusakan hati, sehingga hati tidak dapat melakukan fungsinya dalam mengatur sintesis trigliserida. Sintesis trigliserida yang tidak terkontrol dapat berakibat pada peningkatan kadar trigliserida dalam darah. ${ }^{27}$ Enzim lipoprotein lipase yang berfungsinya dalam menurunkan kadar trigliserida dalam darah mengalami inaktivasi sebagai efek toksik dari alkaloid sehingga kadar trigliserida dalam darah tidak dapat diturunkan. Pada pemberian ekstrak alkaloid biji Garcinia kola sebanyak $1000 \mathrm{mg} / \mathrm{kgBB}$ tikus dapat meningkatkan kadar trigliserida secara signifikan dibanding dengan kelompok kontrol. ${ }^{26}$

Selain berkurangnya kemampuan yoghurt koro pedang dalam menurunkan kadar trigliserida, terdapat faktor lain yang menyebabkan kadar trigliserida meningkat dalam darah seperti peningkatan total kalori asupan. Total kalori yang diasup pada kelompok $\mathrm{K}, \mathrm{P} 1$ dan $\mathrm{P} 2$ mengalami peningkatan yang bermakna selama pemberian yoghurt koro pedang. Peningkatan trigliserida searah dengan terjadinya peningkatan total kalori asupan. Peningkaan total kalori asupan yang bermakna juga berdampak pada kenaikan berat badan kelompok K, P1 dan P2. Semakin banyak jumlah asupan makan disertai kurangnya aktivitas (subjek diletakkan dalam kandang individu dengan aktivitas yang terbatas), maka kalori dari makanan yang tidak digunakan tubuh akan disimpan dalam bentuk trigliserida sebagai cadangan energi. ${ }^{1}$

Peningkatan total kalori pada kelompok kontrol terjadi pada 5 subjek, sedangkan pada 2 subjek mengalami penurunan asupan total kalori. Penurunan asupan total kalori diduga berpengaruh terhadap penurunan kadar trigliserida pada 2 subjek. Selain itu, kandungan $\beta$-conglycinin kedelai pada pakan standar juga berpengaruh terhadap penurunan kadar trigliserida dengan mekanisme peningkatan $\beta$-oksidasi asam lemak, menurunkan sintesis asam lemak dan meningkatkan ekskresi trigliserida melalui feses. ${ }^{28}$

\section{SIMPULAN}

Pemberian yoghurt koro pedang dengan dosis $2,1 \mathrm{ml}$ dan 4,5 $\mathrm{ml}$ selama 21 hari tidak dapat menurunkan kadar trigliserida pada tikus Sprague dawley hipertrigliseridemia. Perlu dilakukan pengujian kadar fitokimia pada yoghurt koro pedang.

\section{DAFTAR PUSTAKA}

1. Raymond JL and Couch SC. Medical Nutrition Therapy for Cardiovaskuler Disease. In Mahan LK, Stump SE, editors. Krause's Food, Nutrition, and Diet Therapy. 13th ed. USA:Saunders; 2012 p. 743-753

2. Stapleton PA, Goodwill AG, James ME, Brock RW and Frisbee JC. Hypercholesterolemia and microvascular dysfunction: interventional strategies. Journal of Inflammation 2010, 7:54 
3. An Endocrine Society Clinical Practice Guideline. Evaluation and Treatment of Hypertriglyceridemia. Journal of Clinical Endocrinology \& Metabolism, September 2012, 97:2969-2989.

4. Word Healty Organization. Indonesia. Non Communicable Disease Country Profile 2011 [cites 2013 may 2]. Available from URL: http://www.who.int/nmh/counries/idn_en.pdf

5. Mahan LK and Stump SE. Krause's Food, Nutrition, and Diet Therapy. 12th ed. USA:Saunders; 2008 p.847

6. Sridhars KR and Seena S. Nutritional and antinutritional significance of four unconvesional legumes of the genus Canavalia - A comparative study. Food Chemistry 99(2006) 267-288

7. Istiani Y. Karakterisasi senyawa bioaktif isoflavon dan uji aktivitas antioksidan dari ekstrak etanol tempe berbahan baku koro pedang (Canavalia ensiformis) [thesis]. Surakarta: Universitas Sebelas Maret. 2010.

8. Vadivel V, Cheong JN and Biesalski HK. Antioxidant and type II diabetes related enzyme inhibition properties of methanolic extract of an underutilized food legume, Canavalia ensiformis (L) DC: Effect traditional processing methods. Food science and Technology 47 (2012) 255-260

9. Departement of Biochemistry Universitas of Benin (Nigeria). Effect of aqueous extract of Canavalia ensiformis seeds on hyperlipidaemia and hyperketoanemia in alloxan-induced diabetes rats. BIOKEMISTRY 2003 June 15(1): 7-15.

10. Riyanto S. Pengaruh pemberian yougrt kedelai hitam (Black soyhurt) terhadap pofil lipid tikus hiperkolesterolemia (skripsi). Semarang:UNDIP. 2011

11. Sundari S. Pengaruh Pemberian Yoghurt Kedelai Hitam (Black Soyghurt) terhadap Kadar Kolesterol Total dan Trigliserida pada Laki-laki Penderita Dislipidemia Usia 40-55 Tahun. Artikel Penelitian Mahasiswa Program Studi Ilmu Gizi. FK Undip Semarang. 2012.

12. Rucita A. Pengaruh Pemberian Yoghurt Kedelai Hitam (Black Soyghurt) terhadap Kadar Kolesterol LDL dan HDL pada Penderita Dislipidemia. Artikel Penelitian Mahasiswa Program Studi Ilmu Gizi. FK Undip Semarang. 2012.

13. Sulistyowati. Pemanfaatan Yoghurt Sebagai Bahan Penurun Trigliserida Darah Manusia. WAHANA, Vol. 51, No. 2, Des 2008.

14. Homayouni A, Payahoo L and Azizi A.Effect of probiotik on lipid profile : a review. American Journal of Food Technology 2012;7(5): 251-265.

15. Ooi LG and Liong MT. Cholesterol-Lowering Effect of Probiotik and Prebiotics: A Review of in Vivo and in Vitro Findings. Internasional Journal of Molecular Sciences. 2010,11,2499-2522.

16. Sprague Dawley® Aged Outbred Rat. http://www.harlan.com/products_and_services/rese arch_models_and_services/research_models/sprag ue dawley aged outbred rat.hl.

17. Onuorah CE, Adejare AO and Uhira NS. Comparative Physico-chemical Evaluatio of Soymilk and Soya cake Produced by Three Different Methods. Nigerian Food Journal, 2007 vol. 25 no. 2 .

18. Kanda H, Wang HL, Hessiltine CW and Warner K. Yoghurt Production by Lactobacillus Fermentation of soybean Milk. Process Biochemistry May 1976 p 3941-3944.

19. World Health Organization (WHO). General Guidelines for Methodologies on Research and Evaluation of Traditional Medicine. Geneva : WHO;2001.

20. Paget G, Barnes J. Toxicity test. In: Laurence DR, Bacharach AL, editors. Evaluation of Drug Activities: Pharmacometrics. London, New York: Academic press; 1964. p. 161-162.

21. Valtek Diagnostic. Total Cholesterol ( CHODPAP), HDL Cholesterol, LDL Cholesterol, Trigliserid http://www.valtekdiagnostics.com

22. Dahlan MS.. Statistika untuk Kedokteran dan Kesehatan Uji Hipotesis. Seri Statistik. PT Arkans: Jakarta 2004.

23. Gropper SS, Smith JL and Groff JL. Advance Nutrition and Human Metabolism. 5th ed.USA: Wadsworth.2009. p 143-146.

24. Perona JS, Canizares J, Montero E, SanchesDominguez M, Phaheco YM, Riuz-Gutierez V. Dietary virgin olive oil triacylglycerols as a independent determinan of very-low density lipoprotein comosition.Nutrition 2004; 20:509-14.

25. Marimurthi $M$ and Krisnamoerthi K. In Vitro Antioxidant Potential of Chlorofrom Seed Extract of Underutilized/Less Edible South Indian Legumes. An International Journal of Advances in Pharmaceutical Sciences. PHARMANEST. Vol 4/Issue4/July-Agust 2013. P 647-658.

26. Ibekwe HA, Adinya IB, Onyeama HP, Akpan IA. Diet dan alkaloid extract of Garcinia Kola induction in serum levels of selected indices of coronary heart disease and liver function. African Journal of Food Science and Technologhy(ISSN:2141-5455) Vol.4(4) pp.80-83, April 2013.

27. Sari LJ. Gambaran hispatologi hati tikus (Rattus rattus) pada uji toksik sub-akut senyawa asam amino non-protein daun lamtoro merah (Acacia villosa). Undergraduate thesis. IPB.2006.

28. Moriyama $\mathrm{T}$, Kishimoto $\mathrm{K}$, Nagai $\mathrm{K}$, Urade R, Ogawa T, Utsumi S, Maruyama N et al. Soybean $\beta$-Conglycinin Diet Supresses Serum Trigyceride Levels in Normal and Genetically Obese Mice by Induction of $\beta$-Oxidation, Downregulation of Fatty Acid Synthase, and Inhibition of Trigyceride Absorbtion. Biochem 2004; 68(2) 352-359. 